\title{
MAKNA KOMPETENSI EMOSI BAGI MANAJER DALAM PENGAMBILAN KEPUTUSAN
}

\author{
Andi Nasrawati Hamid \\ Fakultas Psikologi Universitas Negeri Makassar \\ adisty0603@yahoo.com
}

\begin{abstract}
ABSTRAK
Penelitian kualitatif dengan pendekatan fenomenologi ini bertujuan untuk memahami makna kompetensi emosi bagi manajer dalam melakukan proses pengambilan keputusan di ruang lingkup organisasi. Keterlibatan emosi tidak dapat dihindari ketika individu menghadapi kondisi pengambilan keputusan, oleh karena itu dibutuhkan keterampilan yang berbasis potensi emosi dan berdampak pada pencapaian kinerja yang tinggi. Penelitian ini menggunakan teknik wawancara yang mendalam untuk mengumpulkan data dari responden. Pengumpulan responden dengan menggunakan teknik "snowball" dan pemilihan responden menggunakan purposive sampling. Penelitian kualitatif fenomenologi ini terdiri dari empat proses yang dilalui yaitu epoche, phenomenological reduction, imaginative variation, dan synthesis of meaning. Proses analisis dan interpretasi data meliputi: bracketing, horizonalizing, meaning units untuk mendapatkan deskripsi tekstural; imaginative variation untuk mendapatkan deskripsi struktural; dan memadukan deskripsi tekstural dan struktural menjadi suatu makna yang universal dan mewakili responden secara keseluruhan. Validitas hasil penelitian dengan menggunakan intersubjective validity. Hasil penelitian menunjukkan bahwa pengalaman emosi merupakan sejumlah perasaan yang telah dialami manager dalam mengambil keputusan. Emosi yang dialami berupa: senang, kecewa, marah, dan cemas, yang ditimbulkan oleh adanya intervensi lingkungan, kondisi yang pasti dan ketidakpastian, serta terbatasnya kemampuan dalam menghadapi masalah dan adanya masalah pribadi yang dihadapi oleh manager. Sejumlah perasaan ini dimaknai sebagai sumber motivasi ataupun sebagai sumber stressor yang akan mempengaruhi cara atau strategi manager dalam mengambil keputusan. Kompetensi emosi menjadi sumber strategi manager dalam mengelolah emosi ketika melakukan proses pengambilan keputusan. Adapun bentuk kompetensi emosi manager dalam melakukan proses pengambilan keputusan yaitu: memahami emosi diri, mengendalikan emosi, memiliki motivasi, berempati, memiliki keterampilan sosial.
\end{abstract}

Keyword: Pengalaman emosi, kompetensi emosi, manager, pengambilan keputusan

\section{PENDAHULUAN}

Pengambilan keputusan adalah pekerjaan utama manajer, bahkan manajer sering disebut sebagai pengambil keputusan (decision maker). Walaupun banyak keputusan yang diambil itu strategis sifatnya, manajer juga mengambil keputusan tentang setiap aspek lain dari organisasi, termasuk diantaranya struktur, sistem kontrol, respon terhadap lingkungan, dan sumber daya manusia.. Keputusan mengubah banyak hal, untuk kebaikan dan sebaliknya. Keberhasilan manajer sebagian besar tergantung pada konsekuensi pilihan yang diputuskan. Oleh karena itu penting untuk menjawab pertanyaan "bagaimana manajer mampu membuat keputusan yang efektif?"

Pengambilan keputusan merupakan suatu proses dan berlangsung dalam suatu sistem. Hal tersebut perlu disadari oleh seorang manajer agar dapat berhasil dalam upaya mengembangkan kemampuan untuk mengambil keputusan. Manajer yang mampu mengenali masalah-masalah yang selalu dihadapi di dalam perjalanan menuju kemajuan organisasi, maka semakin mampu untuk mengatasi atau memecahkan masalah-masalah tersebut. Sistem dimana proses pengambilan keputusan itu berlangsung terdiri atas berbagai unsur atau elemen dan masing-masing merupakan suatu faktor yang ikut menentukan segala apa yang terjadi atau yang akan terjadi. Unsur utama dan mungkin yang terpenting di dalam proses pengambilan keputusan adalah masalah. Sesuatu barulah merupakan masalah atau problem, dilihat dari segi pengambilan keputusan bilamana manajer sebagai pemimpin 
dalam organisasi mempunyai tujuan yang jelas dan tegas.

Ekspresi emosi yang positif di tempat kerja secara positif terkait dengan kepuasan kerja. manajer yang mengekspresikan apa yang dirasakannya terkait dengan keputusan yang telah diambil ketika sedang berinteraksi dengan klien atau bawahannya cenderung lebih sehat, merasakan pemenuhan kebutuhan pribadi yang lebih kuat dan merasa lebih lekat dengan pekerjaannya (Hess, 2003).

Seorang manajer tidak dengan sendirinya menjadi rasional ketika ia masuk ke dunia kerja, manusia tetaplah manusia, yang juga memiliki persoalan-persoalan di luar tempat kerjanya yang mempengaruhinya bereaksi terhadap karyawan lainnya, terkadang destruktif atau sebaliknya konstruktif. Hal ini menunjukkan tempat kerja pun penuh dengan nuansa emosi. Di tempat kerja terdapat budaya organisasi yang secara sosial mengatur mengenai emosi-emosi apa yang bisa diekspresikan dan bagaimana emosi tersebut dikelola, mana yang diterima, mana yang tidak. Faktor emosi memiliki peran penting dalam proses pengumpulan informasi, pemilihan alternatif solusi dan pengambilan keputusan. Secara umum, emosi mempengaruhi cara manajer dalam membuat keputusan (Hoch, Kurnreuther, \& Gunther, 2001).

Emosi adalah sesuatu yang sifatnya subjektif. Subjektivitas dari emosi ini dapat menjadi kekuatan yang sangat besar yang tidak mungkin direfleksikan seluruhnya dalam perilaku individu tetapi dalam bentuk pengalaman emosi (emotional experience) yang sangat berperan dalam menentukan perilaku seseorang (Strongman, 2003). Oleh karena emosi sangat mempengaruhi kinerja manajer sebagai seorang decision maker. Sehingga evaluasi, pengembangan dan perawatan emosi di perusahaan perlu terus diupayakan untuk meningkatkan produktivitas, namun harus dengan cara lain yang lebih kualitatif, seperti: observasi, wawancara, analisis lingkungan kerja, dan lain-lain . Memang hasilnya bisa subyektif, tidak obyektif, tetapi yang jelas tidak spekulatif. Dan dalam psikologi, subyektivitas adalah hal yang biasa, sejauh dilakukan oleh profesional yang sudah berpengalaman.

Konsep kompetensi emosi merupakan fenomena yang masih terbilang baru dalam dunia psikologi industri dan organisasi, akan tetapi penggunaannya dalam dunia kerja saat ini sangat dibutuhkan.
Kompetensi emosi memungkinkan seseorang untuk mengelola emosinya dengan baik, sehingga terekspresikan secara tepat dan efektif, yang pada akhirnya akan membawa orang tersebut mampu mengatasi masalah yang dihadapinya, mengambil keputusan, terkait dengan pembuatan dan implementasi suatu kebijakan atau prosedur dengan lancar menuju pencapaian sasaran dan tujuan organisasi secara efektif.

Untuk mengetahui dan memahami makna kompetensi emosi bagi manajer dalam proses pengambilan keputusan maka perlu dilakukan penelitian dengan menggunakan penelitian kualitatif fenomenologi. Secara singkat, fenomenologi adalah menggambarkan arti dari pengalaman hidup (lived experienced) dari beberapa individu mengenai suatu konsep atau phenomenon (Creswell, 1998), pengalaman tersebut diperoleh dari first-person reports atau dengan kata lain untuk menggambarkan (mengidentifikasi) fenomena melalui bagaimana fenomena tersebut dipandang oleh pelaku dalam suatu situasi dan menekankan pada pentingnya perspektif dan interpretasi individu. Phenomenon (fenomena) sendiri berasal dari bahasa yunani, phaenestnai yang berarti menyala tiba-tiba (the flare $u \mathrm{p}$ ), menunjukkan dirinya sendiri (to show itself), kemunculan (to appear). Dari kata dasar phano, phenomenon berarti, "to bring to light, to place in brightness, to show itself in itself, the totally of what lies before us in the light of day" (Moustakas, 1994).

Pemahaman yang terbentuk dari fenomenologi terutama ditujukan pada individu yang mau berpikir (merefleksi) melalui pengalaman hidup diri mereka sendiri sehingga memungkinkan untuk melakukan tindakan yang lebih bermakna dalam konteks yang lebih luas (Burch, 1990). Melalui penelitian fenomenologi, pengalaman emosi manajer sebagai decision maker dalam melaksanakan tugas dan tanggungjawabnya akan menjadi refleksi karyawan atau manajer yang lain, karena kesadaran yang dimanifestasikan dalam pengalaman seseorang (manajer) akan membentuk persepsi dalam memandang sesuatu, sehingga penerimaan individu terhadap sesuatu yang terjadi akan berbeda-beda dan dalam berbagai cara yang unik. Dengan kata lain, persepsi yang terbentuk ini akan menentukan bagaimana reaksi dan perilaku seseorang dalam menanggapi sesuatu (Strongman, 2003). 
Pemahaman yang terbentuk dari fenomenologi terutama ditujukan pada individu yang mau berpikir (merefleksi) melalui pengalaman hidup diri mereka sendiri sehingga memungkinkan untuk melakukan tindakan yang lebih bermakna dalam konteks yang lebih luas (Burch, 1990). Melalui penelitian fenomenologi, pengalaman emosi manajer sebagai decision maker dalam melaksanakan tugas dan tanggungjawabnya akan menjadi refleksi karyawan atau manajer yang lain, karena kesadaran yang dimanifestasikan dalam pengalaman seseorang (manajer) akan membentuk persepsi dalam memandang sesuatu, sehingga penerimaan individu terhadap sesuatu yang terjadi akan berbeda-beda dan dalam berbagai cara yang unik. Dengan kata lain, persepsi yang terbentuk ini akan menentukan bagaimana reaksi dan perilaku seseorang dalam menanggapi sesuatu (Strongman, 2003). Penelitian ini bertujuan untuk memperoleh gambaran emosi dalam proses pengambilan keputusan yang dilakukan oleh manajer di tempat kerja. Penelitian ini lebih lanjut mencoba untuk memahami makna kompetensi emosi bagi manajer dalam melakukan proses pengambilan keputusan dalam perusahaan.

Berdasarkan pendapat para ahli maka dapat disimpulkan bahwa pengambilan keputusan adalah proses yang dilakukan melalui pertimbangan tertentu di dalam memilih alternatif terbaik untuk menyelesaikan suatu persoalan di dalam organisasi sesuai dengan tingkat manajemen dalam suatu organisasi yang dipengaruhi oleh banyak kekuatan termasuk lingkungan organisasi dan pengetahuan, kecakapan, kompetensi dan motivasi.

Pengambilan keputusan merupakan suatu proses mempersatukan memori, pemikiran, proses informasi dan penilain secara evaluatif dalam rangka proses seleksi dari sejumlah alternatif yang tersedia untuk mencapai tujuan yang diinginkan. Pengambilan keputusan akan mudah dilakukan dan lebih efektif, jika seseorang memiliki sejumlah pengetahuan, skill, kompetensi, serta motivasi kerja karena telah memiliki kerangka berpikir secara rasional dan memiliki kepercayaan pada diri sendiri, sehingga mampu menganalisa permasalahan, kemudian mampu menyelesaikan masalah secara kritis.

Wood, Wallace, dan Zeffane (2001) menerangkan tentang kondisi-kondisi (khususnya informasi) yang mempengaruhi pengambilan keputusan yaitu kondisi kepastian, resiko, dan kondisi ketidakpastian. Menurut pendapat Dunnette \& Hough (1998) dan Beach \& Connolly (2005) diketahui bahwa dalam proses pengambilan keputusan terdapat kondisi ketidakpastian yang dapat dibedakan ke dalam kondisi probabilistic uncertainty dan utility uncertainty. Probabilistic uncertainty merupakan kemungkinan ketidakpastian akan suatu resiko yang akan terjadi. Utility uncertainty merupakan kurangnya pengetahuan untuk mengantisipasi resiko yang akan terjadi. Menurut Gibson, dkk, (1997) terdapat beberapa faktor perbedaan individual yang berpengaruh dalam pengambilan keputusan pada level manajer, yaitu:

a. Nilai; Pengaruh nilai dalam pengambilan keputusan terdapat dalam sasaran, mengembangkan alternatif, memilih alternatif, melaksanakan keputusan dan dalam evaluasi serta pengendalian.

b. Kepribadian; Para pengambil keputusan banyak dipengaruhi oleh kekuatan psikologis, baik disadari ataupun tidak disadari. Ciri-ciri yang berbeda seperti kecerdasan berhubungan dengan fase yang berbeda-beda dari proses pengambilan keputusan.

c. Kecenderungan terhadap resiko; Seorang pengambil keputusan yang agak segan mengambil resiko akan menetapkan sasaran yang berbeda, mengevaluasi alternatif yang berbeda, dan memilih alternatif yang berbeda.

Pengambilan keputusan dalam organisasi sangat erat hubungannya dengan karakteristik personal, yaitu: emotional competence, status, prestige, economic, personality, temperament, intelligent, energy, and attitude. Pengambilan keputusan berpengaruh kuat secara langsung terhadap kinerja individu, dan selanjutnya berpengaruh terhadap efektifitas organisasi (Djatmiko, 2002).

Kesimpulannya bahwa pengambilan keputusan pada level manager dalam organisasi dapat dipengaruhi oleh beberapa faktor, baik dari luar maupun dari dalam individu. Faktor yang mempengaruhi pengambilan keputusan dari luar adalah rutin tidaknya keputusan yang akan diambil, waktu yang tersedia, resiko yang mungkin ditanggung, serta besar kecilnya penerimaan dan dukungan. Faktor dari dalam individu berupa kemampuan penalaran, persepsi, emosi, kreativitas, 
motivasi ditambah dengan nilai-nilai dan sikap, serta karakteristik kepribadian.

Emosi individual dapat memiliki pengaruh yang sangat kuat yang mempengaruhi iklim dan sistem kerja (Lofy, 1998), yang berdampak bagi kesuksesan organisasi (Tran, 1998; Dule wicz \& Higgs, 2000). Ketika kompetensi emosi dimiliki oleh seorang manajer, akan ada peningkatan kerjasama, inovasi, dan efektivitas pengambilan keputusan yang dapat meningkatkan produktivitas dan keuntungan organisasi. Manajer memberikan pengaruh yang kuat pada orang-orang yang bekerja di sekelilingnya. Seorang manajer dengan kecerdasan emosi yang tinggi dapat mengambil hasil dari karyawannya di luar harapan yang telah mereka perkirakan (Johnson \& Indvik, 1999).

Emosi memainkan peran sebagai penyebab dan penyesuai tekanan karena emosi berkaitan dengan persoalan biologis dan psikologis (Rochyati, 2006). Pendapat ini didukung oleh hasil penelitian yang dilakukan oleh Dr. Damasio mengenai peran emosi dalam pengambilan keputusan yang "rasional", penelitian tersebut ingin mengetahui secara seksama tentang apakah sebetulnya yang cacat pada pasien-pasien yang menderita kerusakan sirkuit prefrontal-amigdala. ditemukan bahwa sistem pengambilan keputusan mereka cacat berat, namun tidak menunjukkan adanya penurunan IQ atau kemampuan kognitif. meskipun kecerdasan mereka utuh namun dalam membuat keputusan-keputusan menimbulkan bencana dalam kegiatan usaha dan kehidupan pribadinya dan bahkan dapat terus menerus terobsesi akan suatu keputusan yang amat sederhana. hal ini disebabkan karena mereka telah kehilangan akses ke pembelajaran emosi mereka. secara tegas dikemukakan bahwa perasaan biasanya sangat dibutuhkan untuk pengambilan keputusan rasional. oleh karena itu, emosi sangat penting bagi rasionalitas, dalam liku-liku perasaan dengan pikiran, kompetensi emosi membimbing setiap keputusan yang diambil, bekerja bahu membahu dengan pikiran rasional, mendayagunakan atau tidak mendayagunakan pikiran itu sendiri (Goleman, 1996).

Penelitian yang dilakukan oleh Cappelletti (2005) juga mengemukakan bahwa dengan adanya emosi, pengambil keputusan terhindar dari prokrastinasi yang mungkin terjadi pada model pengambilan keputusan rasional. Emosi memberi suatu kerangka pada permasalahan, di mana terdapat batasanbatasan konsekuensi yang perlu dipertimbangkan dalam rational-decision process (Sweeney \& McFarlin, 2002). Perasaan yang direfleksikan dalam bentuk emosi dan mood akan mempengaruhi proses pembelajaran seseorang. Perasaan akan membuat individu memfokuskan perhatian pada situasi yang sesuai dengan mood mereka pada saat menghadapi suatu kejadian. Individu yang berada pada kondisi perasaan negatif maka cenderung untuk memilih informasi yang negatif dibandingkan dengan yang positif (Greenberg \& Baron, 2003).

Emosi mempengaruhi pilihan perilaku di tempat kerja dan bahkan dapat menentukan seleksi rasional dari tindakan khusus secara efektif dan optimal (Jordan, dkk., 2002). Emosi akan mempengaruhi bentuk dan jenis informasi yang akan dipanggil kembali dari memori. Individu yang berada pada kondisi positif cenderung untuk memikirkan kemungkinankemungkinan positif dan optimis akan keputusan yang diambilnya. Individu yang sedang bahagia akan optimis terhadap besarnya kemungkinan memberikan hasil keputusan yang positif, begitu juga sebaliknya (Fineman, Sims, dan Gabriel, 2005).

Perasaan mempengaruhi pilihan akan strategi pengambilan keputusan. Individu yang berada pada kondisi perasaan positif cenderung untuk mengurangi kompleksitas dalam pengambilan keputusan dengan memilih proses yang lebih sederhana dalam memanggil kembali informasi yang akan dipanggil. Mereka akan mengabaikan informasi yang tidak relevan, mempertimbangkan dimensi yang lebih sedikit, informasi yang diperiksa kembali lebih sedikit, serta lebih cepat dalam pengambilan keputusan (Fineman, Sims, \& Gabriel, 2005). Emosi secara sadar (consiousness) diwujudkan dalam bentuk pengalaman emosi, yang merupakan representasi mental yang meliputi: past feelings (memori), hipotetical feelings (imajinasi), atau perasaan yang sedang berlangsung (on-line experience). Representasi mental yang dimanivestasikan dalam bentuk pengalaman emosi ini dapat dieksplorasi melalui self-report (verbal behavior) (Barret, dkk., 2007).

Hoch, Kunreuther, dan Gunther (2001) mengemukakan bahwa emosi berasal dari penilaian kognitif yang terdiri dari penilaian primer dan penilaian sekunder. Pada penilaian primer, individu mempertimbangkan tingkat 
kepentingan dari suatu kejadian, dan apakah membahayakan atau mengancam. Pada penilaian primer akan melibatkan identitas atribut dan nilai di mana interaksi identitas atribut dan nilai akan mempengaruhi emotional trade-off difficulty. Emotional trade-off difficulty ialah ketika terjadi konflik nilai berbagai atribut ketika atribut tersebut dihadapkan pada tujuan yang penting. Ketika berhubungan dengan seberapa penting dampak dari suatu keputusan, maka akan melibatkan beberapa penilaian:

1. Goal relevance, apakah pengambil keputusan dihadapkan pada relevansinya terhadap suatu tujuan tertentu.

2. Goal congruence, apakah pengambil keputusan akan terlibat terhadap dampak positif dan negatif, berdasarkan tujuan dari si pengambil keputusan.

3. Goal content, tujuan apa yang dipertaruhkan dan apakah akan mempengaruhi bentuk pengalaman emosional.

Sedangkan pada penilaian sekunder, individu akan mempertimbangkan sumber daya coping yang tersedia. Pembuat keputusan akan menghindari kesulitan emosional.

Pada proses pengambilan keputusan dengan setting tingkat emosi yang rendah, pengambil keputusan akan menghabiskan lebih banyak waktu dan mempertimbangkan lebih banyak informasi dalam menghasilkan keputusan. Para pengambil keputusan ini akan mengunakan strategi problem-focused coping untuk menghasilkan keputusan yang lebih akurat. Sedangkan ketika berada pada setting emosi yang tinggi, para pengambil keputusan akan menggunakan strategi emotional-focused coping yang akan melibatkan usaha-usaha untuk menghindari distress dari emotional trade-off difficulty (Hoch, Kurnreuther, \& Gunther, 2001).

Penelitian yang dilakukan adalah untuk mengetahui makna kompetensi emosi dalam pengambilan keputusan pada level manager, maka permasalahan penelitian ini dapat dirumuskan dalam grand tour question (pertanyaan pokok) yaitu "bagaimana makna kompetensi emosi bagi manajer dalam proses pengambilan keputusan ?"

Untuk memperkaya (memperdalam) grand tour question, maka dibuat sub pertanyaan seperti berikut ini:

1. Bagaimana bentuk pengalaman emosi manager dalam proses pengambilan keputusan?
2. Faktor-faktor apa yang melatarbelakangi munculnya pengalaman emosi manager?

3. Bagaimana pengaruh kompetensi emosi terhadap pengambilan keputusan yang dilakukan oleh manager?

\section{METODE PENELITIAN}

Penelitian ini menggunakan metode fenomenologi. Ada beberapa proses inti (core process) yang akan dilakukan dalam penelitian fenomenologi ini, yaitu: epoche, reduction, imaginative variation, dan synthesis of meanings and essences (Moustakas, 1994). Muchinsky (2000) menggunakan model penelitian kualitatif untuk melihat dampak emotional narrative terhadap well being dari anggota tim selama dilakukannya penelitian yang sensitif. Data dikumpulkan dari partisipan melalui in-depth interview untuk mengeksplorasi isu-isu sensitif terkait emosi seperti kehilangan seseorang dan kesedihan. Proses penelitian ini dapat membangkitkan respon emosional yang sangat tinggi pada partisipan dan pihak lain yang terlibat dalam penelitian.

Penelitian ini melibatkan manajer yang bekerja (berkarir) di PT. BOSOWA CORPORATION, yaitu salah satu perusahaan swasta yang bergerak di bidang manufaktur, meliputi Direktur Pemasaran, Chief Executive Secretary Corporate, manajer keuangan, dan para eksekutif yang aktif dalam tim "Bosowa Excelent". Para responden ini telah memiliki pengalaman sebagai manajer minimal selama 3 tahun, sebagai penentu kebijakan perusahaan yang saat ini sedang melakukan usaha untuk memajukan dan mengembangkan perusahaan tersebut dan mengadakan perubahan organisasi yang mengarah pada go public (TBK) yang tadinya saham perusahaan dimiliki oleh pemilik tunggal.

Para responden dikumpulkan dengan cara "snow-ball", yaitu melalui referensi dari seorang relasi atau teman atau responden ke responden yang lain, dan seterusnya. Pengumpulan data dilakukan dengan menggunakan metode observasi dan interview yang mendalam. Teknik sampling yang digunakan adalah purposive sampling, yaitu metode yang digunakan untuk memperoleh individu yang kredibel sesuai dengan karakteristik responden yang telah ditentukan yang dapat memberikan kontribusi dalam penelitian (Strauss \& Corbin, 1990).

Langkah pertama yang dilakukan untuk verifikasi data adalah dengan membagikan 
salinan deskripsi secara tekstural-struktural dari pengalaman responden (Humphrey dalam Moustakas, 1994). Kemudian tiap responden diminta untuk secara hati-hati memeriksa deskripsi tersebut, mereka dapat memberikan tambahan masukkan dan pembetulan. Terakhir, peneliti merevisi kembali pernyataan sintesisnya. Proses ini disebut intersubjective validity, yaitu menguji kembali (testing out) pemahaman peneliti dengan pemahaman responden melalui interaksi sosial yang timbal balik (back-and-forth) (Creswell, 1998).

\section{HASIL \& PEMBAHASAN}

Berdasarkan proses intersubjective validity yang dilakukan terhadap responden, diperoleh hasil sebagai berikut: Pertama, para responden memberi penekanan kembali bahwa pengambilan keputusan yang dilakukan di ruang lingkup perusahaan Bosowa Corporation memang menimbulkan pengalaman emosi bagi mereka. Hal ini disebabkan oleh berbagai kondisi atau kejadian yang muncul dalam melakukan proses pengambilan keputusan. Adanya kondisi yang dapat diprediksi, ketersedian data atau informasi yang dibutuhkan, sarana yang memadai, serta masukan dari pihak lain menimbulkan rasa senang dan berani mengambil keputusan dengan cepat. Namun adanya kesalahan data dari bawahan karena mereka memberikan informasi hanya sekedar untuk memyenangkan atasan saja, adanya kesalahan prosedur dalam melaksanakan instruksi atasan menimbulkan rasa marah dan jengkel. Barret (2006) yang mengemukakan bahwa pengalaman emosi merupakan perasaan yang disadari yang timbul karena adanya kejadian atau kondisi tertentu, sehingga mereka berperilaku dalam menanggapi situasi tersebut.

Manager juga akan merasa kecewa apabila target tidak tercapai akibat kesalahan yang terjadi selama proses kerja. Mereka menganggap bahwa hasil yang tepat diperoleh dari proses yang benar dan tepat pula. Selain itu ketika manager diperhadapkan pada situasi yang tidak dapat diprediksi, misalnya adanya perubahan organisasi berupa restrukturisasi, hal ini dapat menimbulkan rasa cemas dan takut kehilangan jabatan, takut mengambil resiko sehingga cenderung "cari aman saja", adanya kebijakan owner yang sering berubahubah juga mengindikasikan bahwa top manajemen tidak konsisten dalam menjalankan komitmen untuk melaksanakan perubahan organisasi. Kondisi-kondisi inilah yang memicu timbulnya pengalaman emosi di antara manager. Apabila proses yang dilalui berjalan lancar dan tepat sehingga hasil yang dicapai sesuai tujuan, maka akan menimbulkan emosi yang positif: seperti rasa puas, senang, bahagia, dan bangga. Sementara bila proses mengalami hambatan, terjadi kesalahan yang tidak diinginkan sehingga hasil yang dicapai tidak sesuai dengan tujuan individu maka akan muncul emosi yang negatif seperti marah, takut, cemas, kecewa dan penyesalan. Emosi yang dirasakan individu tersebut dikelompokkan berdasarkan kesesuaian tujuan individu (Lazarus, 1991). Kondisi-kondisi seperti inilah yang akan memicu dinamika pengalaman emosi sehingga menghasilkan perilaku tertentu sebagai cara atau strategi dalam mengambil keputusan.

Kedua, Perasaan dilemma juga seringkali dialami oleh manager ketika diperhadapkan pada pilihan antara masalah pribadi dan masalah yang terkait dengan pekerjaan di kantor, antara kepentingan pribadi dan kepentingan perusahaan. Hal ini dapat memberi dampak yang luar biasa terhadap kondisi psikologis dan kinerja karyawannya dalam menghadapi situasi yang tidak menentu (uncertainty) Situasi yang dihadapi manager tidak menentu sehingga terdapat faktor peluang dan resiko-resiko yang harus dipertimbangkan apabila seorang manager mengambil keputusan. Situasi yang dihadapi merupakan kejadian yang tidak bisa diprediksi sebelumnya, maupun manager menghadapi masalahmasalah yang mengambang (borderline) dan sulit untuk mengambil sebuah keputusan. Situasi yang tidak menentu ini menjadi sumber motivasi individu untuk mengambil keputusan ( Beach \& Connolly, 2005).

Ketiga, pengalaman emosi yang terbentuk dapat berubah-ubah tergantung pada perubahan kondisi atau kejadian yang berlangsung. Adanya dukungan dan masukan dari rekan kerja selaku manager dari departemen lain ketika melakukan koordinasi terkait dengan permasalahan atau kondisi yang dihadapi dan adanya dukungan dari bawahan dalam melaksanakan instruksi kerja dan suplay informasi atau data yang dibutuhkan untuk penyelesaian masalah cenderung menimbulkan sikap optimis dari manager. Motivasi utama individu untuk mendapatkan nasihat maupun masukan dari orang lain adalah keinginan untuk meningkatkan akurasi penilaian dan sebuah harapan bahwa masukan tersebut dapat membantu. Selain akurasi, ada alasan sosial 
individu untuk mendapatkan pertimbangan dari orang lain, yaitu alasan untuk membuktikan diri dan meningkatkan justifikasi terhadap keputusan yang diambil (Kennedy, Kleintmuntz \& Peecher, 1997). Selain itu, mendapatkan pertimbangan juga menyiratkan usaha membagi tanggung jawab dengan orang lain tentang hasil suatu keputusan (Harvey \& Fisher, 1997). Mencari pertimbangan kepada orang lain yang ahli merupakan prosedur korektif dan merupakan sistem dukungan terhadap pengambilan keputusan individual (Frances \& David, 1999).

Keempat, berdasarkan hasil intersubjective validity responden juga menekankan bahwa pada dasarnya pengalaman emosi yang dimaknai oleh responden dapat menjadi sumber motivasi maupun sumber stressor yang akan menentukan cara atau strategi untuk mengelola dengan baik emosi yang dirasakan agar mampu mengatasi atau menghadapi dengan baik situasi yang berlangsung, sehingga dapat mengambil keputusan dengan tepat. cara mereka mengelola emosi inilah yang merupakan wujud dari kompetensi emosi manager. Dengan memiliki kompetensi emosi maka manager dapat tetap mempertahankan eksistensi mereka di perusahaan tersebut, yang tercermin dari perilaku kerja mereka dalam mengambil keputusan-keputusan secara efektif dan tepat.

Dengan demikian dapat dipahami bahwa pengalaman emosi yang dimaknai oleh responden sebagai sumber motivasi yang berdampak terhadap peningkatan kinerja maupun sebagai sumber stressor yang membawa dampak psikologis akan membentuk makna tersendiri dalam mengimplementasikan kompetensi emosi yang mereka miliki sebagai upaya agar tetap mempertahankan eksistensi mereka di perusahaan tersebut. Adapun bentuk kompetensi emosi manager dalam melakukan proses pengambilan keputusan yaitu: 1) memahami emosi diri, 2 2) mengendalikan emosi, 3) memiliki motivasi, 4) berempati, 5) memiliki keterampilan sosial

Timbulnya pengalaman emosi manager dalam menghadapi situasi pengambilan keputusan disebabkan oleh adanya sejumlah kondisi ketidakpastian dan masalah-masalah yang mengambang. Para pengambil keputusan dalam hal ini akan memodifikasi suatu tindakan sehingga situasi ketidakpastian dan ambigu akan menurun. Menurut Kinicki dan Williams (2006) Gaya pengambilan keputusan ada yang orientasi nilai (value orientation) dan toleransi terhadap ambiguisitas (tolerance for ambiguity). Value orientation kecenderungan seseorang terhadap tugas dan teknis pekerjaan atau terhadap kepentingan orang dan kepentingan sosial ketika mengambil keputusan. Sedangkan tolerance for ambiguity merupakan tingkat toleransi seseorang terhadap situasi yang pasti dan jelas atau situasi yang tidak pasti dan berada dalam kondisi yang penuh tekanan dan ketidaknyamanan psikologis. Seseorang yang memiliki tingkat toleransi terhadap ambiguisitas yang tinggi dapat memberikan energi ketika berada dalam situasi yang ambigu atau tidak menentu.

Pada proses pengambilan keputusan dengan setting tingkat emosi yang rendah, pengambil keputusan akan menghabiskan lebih banyak waktu dan mempertimbangkan lebih banyak informasi dalam menghasilkan keputusan. Para pengambil keputusan ini akan mengunakan strategi problem-focused coping untuk menghasilkan keputusan yang lebih akurat. Sedangkan ketika berada pada setting emosi yang tinggi, para pengambil keputusan akan menggunakan strategi emotional-focused coping yang akan melibatkan usaha-usaha untuk menghindari distress dari emotional trade-off difficulty (Hoch, Kurnreuther, \& Gunther, 2001).

Ketika responden menyadari tingkat emosi baik yang emosi rendah atau ketika berada pada tingkat emosi yang tinggi (emosi positif atau emosi negatif) maka mereka akan menunjukkan perilaku berupa: memahami emosi diri, selanjutkan berusaha mengendalikan emosi tersebut dengan cara menyesuaikan diri terhadap kondisi yang dihadapi, membaca situasi yang terjadi di lingkungan, memahami karakter dan style orang-orang yang dihadapi. Kepekaan untuk merasakan situasi secara alamiah, dengan menyadari permasalahan yang timbul di lingkungan individu. Sensitivitas terhadap masalah merupakan salah satu aspek penting dalam menentukan pilihan dikotomi di samping keberadaan suatu kriteria penentuan keputusan atau standar yang dijadikan acuan (Sugiyanto, 1994). Mempertimbangkan berbagai informasi dan membuat alternative tindakan penyelesaian masalah, berinisiatif melakukan tindakan-tindakan yang bersifat inovatif, serta optimis bahwa setiap masalah dapat terselesaikan, optimis bahwa target kerja akan tercapai. Selanjutnya melakukan interaksi dengan pihak lain dengan berkomunikasi 
secara efektif, berusaha "mengintimidasi" orang lain dan menjalin kerjasama yang baik dengan semua pihak agar bisa mendapatkan dukungan dan masukan untuk membuat keputusan dan kebijakan yang tepat. lingkungan yang mendukung individu untuk dapat memperoleh kejelasan informasi. Komunitas kelompok berperan penting dalam membantu individu untuk mencari dan mendapatkan informasi yang jelas (Ridha, 2003) dan terakhir bertanggung jawab atas semua kemungkinan dampak dan resiko yang muncul. Dapat dilihat bahwa dengan strategi seperti inilah mereka akan tetap mempertahankan diri sebagai pemangku jabatan di lini management selaku decision maker di perusahaan Bosowa Corporation.

\section{KESIMPULAN \& SARAN}

Pengambilan keputusan yang dilakukan pada level managerial di Bosowa Corporation pada umumnya menimbulkan pengalaman emosi bagi manager selaku decision maker. Dalam hal ini proses pengambilan keputusan menimbulkan berbagai bentuk kejadian (event) atau kondisi yang akan dinilai menguntungkan bila sesuai dengan harapan atau tujuan yang ingin dicapai (goal congruent), dan akan dinilai sebagai sesuatu yang mengancam bila tidak sesuai dengan harapan atau tujuan yang ingin dicapai (goal congruent). Kondisi seperti inilah yang pada akhirnya akan menimbulkan pengalaman emosi baik yang berupa pengalaman emosi positif maupun negatif.

Pengalaman emosi yang dialami oleh manager ketika melakukan proses pengambilan keputusan di Bosowa Corporation cenderung beragam. Ada di antara responden yang merasa senang, cemas, marah, dan ada pula responden yang merasa kecewa dengan kondisi yang dihadapinya. Timbulnya pengalaman emosi pada manager disebabkan oleh sejumlah kondisi yang terjadi selama proses pengambilan keputusan, yaitu: 1) Intervensi Lingkungan, 2) Kondisi Kepastian dan ketidakpastian, dan 3) kondisi pribadi manager.

Oleh karena itu timbullah perilaku sebagai cara atau strategi dalam mengambil keputusan yang dinilai efektif dan efisien. Hal ini tergantung pada bagaimana responden memaknai pengalaman emosi yang mereka alami. Ketika terdapat sejumlah kondisi yang dianggap masih menguntungkan bagi responden, maka responden cenderung memiliki semangat dalam melaksanakan aktivitas kerja di tengah ketidakpastian yang ditimbulkan oleh perubahan organisasi yang berlangsung.

Dengan demikian dapat dipahami bahwa pengalaman emosi yang dimaknai oleh responden sebagai sumber motivasi yang berdampak terhadap peningkatan kinerja maupun sebagai sumber stressor yang membawa dampak psikologis akan membentuk makna tersendiri dalam mengimplementasikan kompetensi emosi yang mereka miliki sebagai upaya agar tetap mempertahankan eksistensi mereka di perusahaan tersebut. Adapun bentuk kompetensi emosi manager dalam melakukan proses pengambilan keputusan yaitu: 1) memahami emosi diri, 2) mengendalikan emosi, 3) memiliki motivasi, 4) berempati, 5) memiliki keterampilan sosial

Dari hasil penelitian ini dengan berpijak pada kerangka pemikiran yang ada dan sumbangan kemanfaatan ilmu psikologi bagi kepentingan masyarakat luas, maka terdapat beberapa saran yang dapat dikemukakan sebagai berikut:

Pertama, Pengambilan keputusan merupakan tugas utama manager dalam mengatur dan mengontrol kinerja departemennya dan akan terus terjadi di sepanjang usia organisasi demi mempertahankan eksistensinya. Oleh karena itu, setiap manager hendaknya membekali diri dengan berbagai bentuk kompetensi, khususnya kompetensi emosi sehingga dapat menyesuaikan diri dengan berbagai situasi dan kondisi yang mungkin berlangsung, baik yang sifatnya terprogram maupun yang tidak terprogram, yang dapat diprediksi maupun yang tidak terprediksi. Setiap kebijakan yang dibuat semestinya direalisasikan secara konsisten demi tercapainya target dan tujuan bersama. Peran psikologi secara praktis dapat diperluas dengan mengadakan bentuk-bentuk pelatihan pengambilan keputusan di level managerial dan bentuk pelatihan pengembangan kompetensi emosi.

Kedua, pada proses pengambilan keputusan dengan tingkat emosi yang rendah atau sedang mengalami emosi negatif, pengambil keputusan akan menghabiskan lebih banyak waktu dan mempertimbangkan lebih banyak informasi dalam menghasilkan keputusan oleh karena itu sebaiknya manager memiliki tingkat toleransi yang tinggi terhadap kondisi ketidakpastian dan tidak terencana karena hal ini dapat memberikan energi ketika berada dalam situasi yang ambigu atau tidak menentu. 
Ketiga, bagi peneliti selanjutnya perlu mengetahui bahwa pelaksanaan penelitian ini memerlukan waktu yang lama, khususnya dalam proses pengumpulan dan analisis data sehingga diperlukan keuletan dan kesabaran. Di samping itu, peneliti seharusnya memiliki kemampuan dalam melakukan wawancara secara mendalam karena memadai atau tidaknya data yang diperoleh sangat tergantung pada kemampuan peneliti sebagai instrument penelitian. Penelitian tentang kompetensi emosi dan pengambilan keputusan juga dapat ditindaklanjuti dengan menggunakan pendekatan yang lain seperti eksperimen.

\section{DAFTAR PUSTAKA}

Alsa, A. (2003). Pendekatan Kuantitatif dan Kualitatif serta Kombinasinya dalam Penelitian Psikologi. Yogyakarta: Pustaka Pelajar.

Azwar. (2003). Metode Penelitian. Yogyakarta: Pustaka Pelajar.

Beach, L.R. \& Connolly, T. (2005). The Psychology of Decision Making: People in Organizations. New York: SAGE Publications, Inc.

Burch, R. (1989). Phenomenology and Its Practices. Phenomenology + Pedagogy, 7 , p. 187-217. diakses tanggal 27 januari 2007. http:

//www.phenomenologyonline.com

Burch, R. (1990). Phenomenology, Lived Experience : Taking a Measure of the Topic. Phenomenology + Pedagogy, 8, 130 160. diakses tanggal 27 januari 2007. http: //www.phenomenologyonline.com

Cappelleti, D. (Agustus, 2005). The Impact of Emotions on Probabilistic Decision Making. . Diakses tanggal 06 Januari 2007. http://www.google.com

Cherniss, C. \& Goleman, D. (2002). Emotional Intelligence: Issues in Paradigm Building. Journal The Consortium For Research on Emotional Intelligence in Organizations. Diakses tanggal 06 Desember 2006. http://www.google.com

Clark, M.S. (1992). Review of Personality and Social Psychology. London : Sage Publication

Creswell, J. W. (1998). Qualitative Inquiry and Rearch Design : Choosing Among Five Traditions. California: SAGE Publications, Inc.

Creswell, J. W. (2002). Educational Research: Planning, conducting, and Evaluating
Quantitative and Qualitative Research. New Jersey: Pearson Education, Inc.

Djatmiko, Y. H. (2002). Perilaku Organisasi. Bandung: Alfabeta.

Dulewicz, V. \& Higgs, M. (1999). Can Emotional Intelligence be Measured and Developed? Leadership \& Organization Development Journal, 20: 242-252.

Dulewicz, V. \& Higgs, M. (2000). Emotional Intelligence: A Review and Evaluation Study. Journal of Managerial Psychology, 15: 341-372.

Dunnette, D.M. (1976). Handbook of Industrial and Organizational Psychology

Chicago: Rand McNally College Publishing Company.

Dunnette, D.M. \& Hough, M.L (1998). Handbook of Industrial and Organizational Psychology Volume Three. Joico Publishing House.

Fineman, S., Sims, D., \& Gabriel, Y. (2005). Organizing and Organizations. London: SAGE Publications, Inc.

Faturrochman. (1997). The Job Characteristics Theory. Buletin Psikologi, V (2).

Frances, J. M. \& David, A.V. (1999). Strategc Descision Making Task and Group Efektitiveness: Insights from Theory and Reserch on Small Group Performance. Human Relation, Vol. 44, No. 12, p. 1229-1253.

Gibson, J.L., Ivancevich, J.M., \& Donnelly, J.H., (1997). Organizations Behavior Structure Processes. Boston: Irwin McGraw-Hill.

Gitosudarmo \& Sudita. (1997). Perilaku Organisasi Edisi Pertama. Yogyakarta: PFE UGM.

Goleman, D. (1996). Emotional Intelligence. Jakarta : PT Gramedia.

(2003). Kecerdasan Emosi Untuk Mencapai Puncak Prestasi. Jakarta: PT Gramedia.

, Boyatzis, R. \& McKee. A. (2004). Primal Leadership: Kepemimpinan Berdasarkan Kecerdasan Emosi. Terjemahan Primal Leadership: Realizing The Power of Emotional Intelligence. Jakarta: PT. Gramedia Pustaka Utama.

Greenberg, J., \& Baron, R.A. (2003). Behavior in Organizations. New Jersey: Prentice Hall.

Griffin, R. W. (1984). Management. Boston: Houghton Mifflin Company. 
Harvey,N. \& Fischer, I. (1997). Taking Advice: Accepting Help, Improving Judgment and Sharing Responsibility. Organizational Behavior and Human Decision Processes, 70, 117-133

Hess, U. (2003). Emotion at Work. Burgundy Report. Montreal: CIRANO (Center for Interuniversity Research And Analysis on Organizations)

Herbert N. C. (2004). Teknik Pengambilan Keputusan. Yogyakarta: Zenith Publisher.

Hoch, S.J., Kurnreuther, H.C., Gunther, R.E. (2001). Wharton on Decision Making. New York: John Wiley \& Sons, Inc.

Iman, E. (2004). Paradigma Baru Kecerdasan Emosional. Majalah Cakrawala TNI$A L$. Diakses tanggal 06 Desember 2006. http://www.google.co.id

Jagers, R.J. (2001). Cultural Integrity, social and Emotional Competence Promotion: Work Notes on Moral Competence. The Journal of Negro Education. 70, p. 60.

Johnson, P.R. \& Indvik, J. (1999). Organizational Benefits of Having Emotionally Intelligent Managers and Employees. Journal of Workplace Learning. 11, p. 84-88.

Jordan, P J., Ashkanasy, N M., \& Hartel, C E J. (2002). Emotional Intelligence as A Moderator of Emotional and Behavioral Reactions to Job Insecurity. Academy Management Review, 27, p. 361-372.

Kennedy, J. Kleinmuntz, D.N \& Peecher, M. E. (1997). Determinants of The Justifiability of Performance in IllStructured Audit Tasks. Journal of Accounting Research, 35, 105-123.

Kinicki, A., \& Williams, B.K., (2006). Management: A Practical Introduction. New York: The McGraw-Hill Companies, Inc.

Küpers, W. (2003). A Phenomenology of Embodied Passion and The Demotivational Realities of Organization. Paper. To be presented at CMS 2001, Manchester at the Stream.

Lazarus, R S. \& Lazarus, B N. (1991). Passion and Reason: Making Sense of Our Emotion Dalam Muchinsky, P. Journal of Organizational Behavior, 21, p. 801805.

Lazarus, R.S. (1976). Patterns of Adjusment. Japan: McGraw-Hill

Leavitt, H.J. (1978). Psikologi Manajemen Sebuah Pengantar Bagi Individu dan
Kelompok di dalam Organisasi. Jakarta: Erlangga.

Lofy, M.,M. (1998). The Impact of Emotion on Creativity in Organizations. Empowerment in Organizations, 6, p. 512.

Mellers, B.A., Schwartz, A., Ho, K., \& Ritov, I. (1997). Decision Affect Theory: Emotional Reactions to The Outcomes of Risky Options. Psychological Science, 8, p. 423-429.

Moorhead, G. \& Griffin, R.W. (1995). Organizational Behavior Managing People and Organizations. Boston: Hougton Mifflin Company.

Moustakas, C. (1994). Phenomenological Research Methods. California: SAGE Publications, Inc.

Muchinsky, P.M. (2000). Emotions in The Workplace: The Neglect of Organizational Behavior. Journal of Organizational Behavior, 21: 801-805.

Nirman, U. (1999). Perilaku Organisasi. Surabaya: Citra Media.

Postmas, T., Spears, R. \& Cihangir, S. (2001). Quality of Decision Making and Group Norms. Journal Personality and Social Psychology, Vol. 80, No. 6, p 918 - 930.

Prawitasari, J.E. Martani, W. dan Adiyanti, M.E. (1997). Konsep Emosi Orang Indonesia: Pengungkapan dan Pengertian Emosi Melalui Komunikasi Nonverbal di Masyarakat yang Berbeda Latar Belakang Budaya. Laporan Penelitian. (tidak diterbitkan). Yogyakarta: Fakultas Psikologi UGM.

Prihadi, S. (2004). Assessment Centre, Identifikasi, Pengukuran, dan Pengembangan Kompetensi. Jakarta: Gramedia Pustaka Utama.

Reed, S. K. (2000). Cognition: Theory and Applications. California: Wadsworth Thomson Learning

Reksohadiprojo, S. \& Handoko, H. (2001). Organisasi Perusahaan, Teori, Struktur dan Perilaku. Yogyakarta: FE UGM.

Ridha, A. (2003). Cara Cerdas Mengambil Keputusan. Bandung: P.T Syaamil Cipta Media.

Robbins, S.P. (1998). Organizational Behavior Concept, Conrtroversies, Aplication. Prentice Hall Internasional.

Rochyati, I. (2006). Emosi di tempat kerja. Makalah. Tidak dipublikasikan. 
Rowe, A.J., \& Boulgarides, J.D. (1992). Manajerial Decision Making. New York: Macmillan Publishing Company.

Strauss, A. \& Corbin, J. (1990). Basics of Qualitative Research: Grounded Theroy Procedures and Techniques. London: Sage Publication, Inc.

Strongman, K.T. (2003). The Psychology of Emotion: from Everyday Life to Theory. England: John Wiley \& Sons Ltd.

Sweeney, P.D. \& McFarlin, D.B. (2002). Organizational Behavior: Sollutions for Management. America: The McGarwHill Companies, Inc.

Sugiyanto. (1994). Sensitivitas Manusia dalam Menentukan Pilihan Dikotomi Yogyakarta: Buletin Psikologi Universitas Gadjah Mada, Tahun II, No, 1.

Tran, V. (1998). The Role of Emotional Climate in Learning Organization. The Learning Organization. 5, p. 99-103.

Thomas, D.C. \& Inkson, K. (2004). The Handbook of Global Managers. San Fransisco: Berret-Koehler Publishers, Inc.

Wang, C L. \& Ahmed, P K. (2003). Emotion: The Missing Part of System Methodologies. Kybernetes. 32, p. 12831296.

Weber, E.U., \& Hsee, C.K. (2000). Culture and Individual Judgement and Decision Making. Applied Psychology: An International Review. 49 (1). p 32-61.

Wood, Wallace \& Zeffane. (2001). Organisational Behavior: Global Perspective. Australia: John Wiley \& Sons Australia, Ltd. 